Fincham, J. R. S. (1959). J. gen. Microbiol. 21, 600-611

\title{
On the Nature of the Glutamic Dehydrogenase Produced by Inter-Allele Complementation at the am Locus of Neurospora crassa
}

\author{
By J. R. S. FINCHAM \\ Department of Genetics, University of Leicester
}

SUMMARY: A method for the 40-fold purification of glutamic dehydrogenase from Neurospora crassa is described. Strains which are homocaryotic for the alleles $a m^{1}$, $a m^{2}$ or $a m^{3}$ produce no detectable glutamic dehydrogenase, but heterocaryons of composition $a m^{1}+a m^{2}$ or $a m^{1}+a m^{3}$ do possess the enzyme activity. Extracts of $a m^{1}+a m^{2}$ mycelia have $10 \%$, or rather less, of typical wild-type activity when assayed at about $20^{\circ}$. Enzyme preparations from $a m^{1}+a m^{2}$ are distinguished from wild-type preparations in: $(a)$ their capacity for thermal activation as the temperature is raised between $20^{\circ}$ and $35^{\circ} ;(b)$ their low stability at $60^{\circ}$. Extracts of $a m^{1}+a m^{3}$ mycelia show 20-25\% of typical wild-type activity. Enzyme preparations from $a m^{1}+a m^{3}$ are distinguished from wild-type in their lower affinity for glutamate, and they tend also to be more thermolabile than wild-type enzyme, though less so than $a m^{1}+a m^{2}$ preparations. Experiments on mixed enzymes showed no evidence for any effect of either kind of heterocaryon preparation on the properties of wildtype enzyme, or vice versa. It thus seems likely that the effects observed are due to differences in the enzyme molecules themselves. The significance of these observations for theories on the mechanism of inter-allele complementation is discussed.

When a series of different mutations all result in a deficiency in the same enzyme, and all fall within the same very short chromosome segment, they may reasonably be considered as belonging to the same genetic locus (Fincham, 1959). Most commonly, two such 'allelic' mutations will not complement each other to form a non-mutant phenotype when present together in the same cell. However, in a number of cases, both in Neurospora crassa (Pateman \& Fincham, 1958; Woodward, Partridge \& Giles, 1958), and in Salmonella typhimurium (Hartman, Hartman, Serman \& Loper, 1958), where an extensive series of alleles at a locus has been examined, certain pairs of alleles have been shown to be capable of promoting enzyme formation jointly, though unable to do so individually. In previous papers (Fincham, 1959; Pateman \& Fincham, 1958) it was reported that of eleven mutants at the am locus of Neurospora, all of which lack glutamic dehydrogenase activity, only two pairwise combinations of alleles $\left(a m^{1}+a m^{2}\right.$ and $\left.a m^{1}+a m^{3}\right)$ produced the enzyme activity in heterocaryons. An important question in relation to the mechanism of enzyme formation through inter-allele interaction (complementation) is whether the enzyme so produced is normal in its properties. In this paper, evidence will be presented showing that the two pairs of complementary alleles at the am locus produce varieties of glutamic dehydrogenase which are distinguishable from the wild-type enzyme, and from each other. 


\section{METHODS}

Neurospora strains. The wild-type strain ST $A$ of Neurospora crassa was the same as used in previous studies (Fincham \& Pateman, 1957 a), and the wild-types $2 a$ and $5 a$ were closely related to it through inbreeding, as were most of the other strains used in this work. Double mutants carrying both an am allele and either arg-1 or arg-10 were the same as used in a previous study (Pateman \& Fincham, 1958), with the exception of $\mathrm{am}^{3}$ arg-1-2, which was made by the same procedure as the other double mutants. The use of the mutations at the two arg loci, which correspond to two different steps in arginine synthesis (Newmeyer, 1957), permitted the forcing of heterocaryons. Since am strains grow, after a lag, on minimal medium, it is not always possible to be certain that one has a heterocaryon when am single mutants are used. The four heterocaryons used in the present experiments were as follows: $a m^{1}$ arg-10-13 $+a^{3}$ arg-1-2 (het $\left.A\right), a^{1}$ arg-1-1526-78 $+a^{3}$ arg-10-14 (het $\left.\mathrm{B}\right)$,

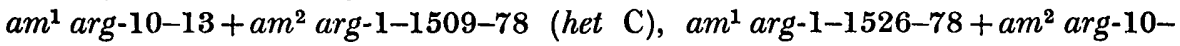
1505-56 (het D). The alleles $a m^{1}, a m^{2}$ and $a m^{3}$ are those formerly referred to as $a m^{32}, a m^{47}$ and $a m^{29}$ respectively (Pateman \& Fincham, 1958).

Enzyme assays. The standard assay system consisted of : 0.005-0.2 ml. of enzyme preparation diluted to $2 \cdot 65 \mathrm{ml}$. with $0 \cdot 1 \mathrm{M}$-sodium phosphate buffer (pH 8.0), $0.1 \mathrm{ml}$. 0.2 M-disodium $\alpha$-ketoglutarate; $0.2 \mathrm{ml}$. reduced triphosphopyridine nucleotide (TPNH) to give an optical density of $0.35-0.40$ at $340 \mathrm{~m} \mu$ in the final mixture; $0.05 \mathrm{ml} .0 .4 \mathrm{M}$-ammonium chloride; the mixture was held in a $1 \mathrm{~cm}$. Unicam SP 500 spectrophotometer cell. The optical density was read at $340 \mathrm{~m} \mu$ before addition of the $\mathrm{NH}_{4} \mathrm{Cl}$, which was added at zero time on a Perspex stirrer. Readings were taken at 15 sec. intervals for 3-5 min., and the initial rate of decrease of optical density was estimated graphically. A change in optical density of 0.001 in $1 \mathrm{~min}$. was taken as the unit of activity, and specific activity was expressed as units/mg. protein. In the assay of crude extracts, and ammonium sulphate fractions which had not been dialysed, the TPNH was added last. Except in the experiments illustrated by Tables 1-3, where assays were carried out at room temperature (about $20^{\circ}$ ), temperature was controlled by a Unicam constant temperature housing attached to the spectrophotometer. While the standard assay made use of the back reaction ( $\alpha$-ketoglutarate $\rightarrow$ glutamate), the rate of the forward reaction was measured in a number of experiments. Here the following standard system was used: enzyme diluted to $2 \cdot 6 \mathrm{ml}$. in $0 \cdot 1 \mathrm{M}$-sodium phosphate buffer (pH 8.0); $0.2 \mathrm{ml} .0 .5 \mathrm{M}$-monosodium glutamate; $0.2 \mathrm{ml} .0 .16 \%$ $(\mathrm{w} / \mathrm{v})$ triphosphopyridine nucleotide (TPN). The TPN was added at zero time and the rate of increase in optical density measured. With the standard reaction mixtures the back reaction was about six times as fast as the forward reaction for the same amount of enzyme.

Enzyme preparations. Cultures were grown from heavy inocula of conidia for $48 \mathrm{hr}$. at $25^{\circ}$ in $100 \mathrm{ml}$. lots of liquid medium $\mathrm{N}$ (Vogel \& Bonner, 1956) in Roux bottles. The resulting mycelium was washed with water, blotted, roughly weighed (the usual yield was 1-1.5 g./bottle) and ground in a chilled 
mortar with powdered glass and about 10 vol. of $0.05 \mathrm{M}$-sodium phosphate buffer ( $\mathrm{pH} \mathrm{8.0)}$. The homogenate was filtered through a pad of kieselguhr by suction. Where further purification was intended, about $1 \mathrm{~g}$. kieselguhr was used for each g. damp weight mycelium. The use of thicker pads of kieselguhr led to some loss of enzyme, but also to a higher specific activity in the filtrate (cf. the values for crude filtrates of wild type in Tables 1 and 2; c. 2-3 g. kieselguhr was used/g. mycelium in the experiments recorded in Table 2). Except where otherwise stated, the data of the present paper refer to enzyme preparations partially purified by the following method. To each $100 \mathrm{ml}$. of crude filtrate, $89 \mathrm{ml}$. saturated ammonium sulphate solution (70 g. dissolved in $100 \mathrm{ml}$. water) was added, and the precipitate was removed by centrifuging. To the supernatant fluid $\mathbf{1 3 \cdot 3}$ g. solid ammonium sulphate was added; the precipitate was collected by centrifuging and dissolved in $20-30 \mathrm{ml} .0 .05 \mathrm{M}$ sodium acetate buffer ( $\mathrm{pH}$ 5-6). Each ammonium sulphate addition was made at close to $0^{\circ}$, over a $10 \mathrm{~min}$. period, and with constant stirring. Centrifuging was for $10 \mathrm{~min}$. at $3000 \mathrm{~g}$ in each case. In some experiments (Table 2) the second

\section{Table 1. Purification of glutamic dehydrogenase from wild-type}

\begin{tabular}{|c|c|c|c|c|}
\hline Fraction & Vol. (ml.) & $\begin{array}{l}\text { Total protein } \\
\text { (mg.) }\end{array}$ & $\begin{array}{l}\text { Total units } \\
\text { (thousands) }\end{array}$ & $\begin{array}{l}\text { Specific } \\
\text { activity }\end{array}$ \\
\hline $\begin{array}{l}\text { Filtered extract of } \\
6 \mathrm{~g} . \text { damp mycelium }\end{array}$ & 50 & 325 & 110 & 340 \\
\hline $\begin{array}{l}\text { Ammonium sulphate } \\
\text { fraction }\end{array}$ & 11 & 93 & 88 & 950 \\
\hline Gel supernatant fluid & 11 & - & 31 & - \\
\hline First gel eluate & 5 & $1 \cdot 3$ & 18 & 13,800 \\
\hline Second gel eluate & 5 & 0.75 & 8 & 10,700 \\
\hline
\end{tabular}

ammonium sulphate precipitate was taken up in $0.05 \mathrm{M}$-sodium phosphate buffer ( $\mathrm{pH} \mathrm{8.0)}$ ) and used as enzyme, with or without prior dialysis against the same buffer. To the fraction dissolved in acetate buffer, enough calcium phosphate gel was added to give 1-1.5 mg. calcium phosphate/mg. protein. The gel was prepared according to the method of Keilin \& Hartree (quoted in Colowick \& Kaplan, 1955), and aged for several months before use. After stirring at room temperature for $10 \mathrm{~min}$., the gel was centrifuged down and resuspended in $10 \mathrm{ml}$. 0.05 M-sodium phosphate buffer (pH 6.5). After a further $10 \mathrm{~min}$. stirring, the gel was again centrifuged and the supernatant fluid (first gel eluate) was saved. The elution was repeated as many times as necessary. Usually the second gel eluate had the highest specific activity, but sometimes the first or the third eluates were better. This procedure (Table 1) gave, in the case of wild-type enzyme, $c$. 40-fold increase in specific activity over the crude filtrate. For the $a m^{1}+a m^{2}$ and $a m^{1}+a m^{3}$ heterocaryons, the purification factors were usually only about 20 -fold and 30 -fold respectively, perhaps because of the lower stability of the enzyme in these mycelia. In some preparations of wild-type enzyme the ammonium sulphate fraction in acetate buffer was heated to $50^{\circ}$ for $4 \mathrm{~min}$., and the precipitate formed was removed 
before addition of the gel. The inclusion of this step probably improved the procedure as a method for purifying wild-type enzyme (an over-all purification of 50-fold was obtained on one occasion), but it resulted in total loss of activity when used on $a m^{1}+a m^{2}$ preparations, so it was not generally used in the present work.

Protein determinations. Protein was determined by the method of Lowry, Rosebrough, Farr \& Randall (1951).

Table 2. Thermostabilities of glutamic dehydrogeriase preparations from Neurospora crassa, wild-type and heterocaryons

\begin{tabular}{|c|c|c|c|c|c|}
\hline \multirow[b]{2}{*}{ Strain } & \multirow[b]{2}{*}{ Type of preparation* } & \multirow{2}{*}{$\begin{array}{l}\text { Protein } \\
\text { content } \\
\text { (mg./ml.) }\end{array}$} & \multicolumn{2}{|c|}{ Specific activity } & \multirow[b]{2}{*}{$\begin{array}{l}\text { Loss } \\
(\%)\end{array}$} \\
\hline & & & $\begin{array}{l}\text { Before } \\
\text { heating }\end{array}$ & $\begin{array}{c}\text { After } \\
\text { heating } \dagger\end{array}$ & \\
\hline \multirow[t]{2}{*}{ Wild type STA } & $\begin{array}{l}\text { Crude filtrate } \\
\text { Ammonium sulphate } \\
\text { fraction }\end{array}$ & $\begin{array}{l}0.75 \\
0.35\end{array}$ & $\begin{array}{l}1070 \\
4540\end{array}$ & $\begin{array}{l}1070 \\
2740\end{array}$ & $\begin{array}{r}0 \\
40\end{array}$ \\
\hline & $\begin{array}{l}\text { Ammonium sulphate } \\
\text { fraction, dialysed }\end{array}$ & $0 \cdot 35$ & 3710 & 3140 & 15 \\
\hline \multirow[t]{2}{*}{$a m^{1}+a m^{2}$, het C } & $\begin{array}{l}\text { Crude filtrate } \\
\text { Ammonium sulphate } \\
\text { fraction }\end{array}$ & $\begin{array}{l}0.92 \\
0.57\end{array}$ & $\begin{array}{r}51 \\
510\end{array}$ & $\begin{array}{r}18 \\
4\end{array}$ & $\begin{array}{l}65 \\
99\end{array}$ \\
\hline & $\begin{array}{l}\text { Ammonium sulphate } \\
\text { fraction, dialysed }\end{array}$ & 0.56 & 261 & 42 & 85 \\
\hline \multirow[t]{2}{*}{$a m^{1}+a m^{2}$ het $\mathrm{D}$} & $\begin{array}{l}\text { Crude filtrate } \\
\text { Ammonium sulphate } \\
\text { fraction }\end{array}$ & $\begin{array}{l}0 \cdot 60 \\
0 \cdot 30\end{array}$ & $\begin{array}{r}55 \\
306\end{array}$ & $\begin{array}{r}25 \\
6\end{array}$ & $\begin{array}{l}54 \\
98\end{array}$ \\
\hline & $\begin{array}{l}\text { Ammonium sulphate } \\
\text { fraction, dialysed }\end{array}$ & $\mathbf{0} \cdot \mathbf{3 3}$ & 103 & 30 & 71 \\
\hline \multirow[t]{2}{*}{$a m^{1}+a m^{3}$ het $\mathrm{A}$} & $\begin{array}{l}\text { Crude filtrate } \\
\text { Ammonium sulphate } \\
\text { fraction }\end{array}$ & $\begin{array}{l}0.90 \\
0 \cdot 50\end{array}$ & $\begin{array}{r}76 \\
385\end{array}$ & $\begin{array}{l}59 \\
88\end{array}$ & $\begin{array}{l}22 \\
77\end{array}$ \\
\hline & $\begin{array}{l}\text { Ammonium sulphate } \\
\text { fraction, dialysed }\end{array}$ & 0.51 & 300 & 183 & 40 \\
\hline
\end{tabular}

* Crude extracts in 0.05 $\mathrm{M}$-sodium phosphate buffer (pH 8.0); the same buffer was used for dissolving the ammonium sulphate fractions, and for dialysing.

$\dagger 15$ min. at $60^{\circ}$.

\section{RESULTS}

Relative specific activities of wild type and heterocaryon preparations

Crude filtrates of wild-type organism have generally shown specific activities in the range 300-500, usually nearer the latter figure. Of the $a m^{1}+a m^{3}$ heterocaryons, het $\mathbf{A}$ and het $\mathrm{B}$ gave, in single experiments, specific activities in crude filtrates of 87 and 93 respectively. Corresponding values for the $a m^{1}+a m^{2}$ heterocaryons were 36 and 40 for het $\mathrm{C}$, and 37 and 36 for het $\mathrm{D}$. Where relatively thick pads of kieselguhr were used for filtration (as in the experiments recorded in Table 2 ) higher specific activities were generally obtained. The best estimates that can be given of average levels of enzyme activity are rather under $10 \%$ for the $a m^{1}+a m^{2}$ heterocaryons, and $20-25 \%$ of wild-type for the $a m^{1}+a m^{3}$ heterocaryons. Production of glutamic dehydrogenase seems to be 
unaffected by the arg-1 and arg-10 mutations in the heterocaryons; a heterocaryon formed between the two single mutants gave activity in the wild type range.

The differences in activity between wild-type and heterocaryon preparations were even more marked after partial purification, because of lower recoveries in the gel elution step in heterocaryon preparations. Recoveries of activity after ammonium sulphate fractionation were always high, and in some experiments on $a m^{1}+a m^{2}$ heterocaryons (e.g. het $\mathrm{C}$ in Table 2) significantly more than $100 \%$ recovery of activity was obtained from the ammonium sulphate fraction. The possibility that, in these cases, new active enzyme was, in effect, being made by co-precipitation of materials contributed by the two alleles, was apparently ruled out by an experiment in which extracts of $\mathbf{a m}^{1}$ and $a m^{2}$ mycelia grown separately and fractionated together yielded no activity. It seems probable that some activation of the enzyme from $a m^{1}+a m^{2}$ heterocaryons may occur during fractionation.

Table 3. Thermostabilities of Neurospora crassa wild-type and heterocaryon $\left(\mathrm{am}^{1}+\mathrm{am}^{2}\right)$ glutamic dehydrogenase preparations separately and in mixture

Dialysed ammonium sulphate fractions in $0.05 \mathrm{~m}$-sodium phosphate buffer (pH 8.0). Protein concentrations : $0.075 \mathrm{mg} . / \mathrm{ml}$. of wild-type (ST $A$ ) and $1.4 \mathrm{mg} . / \mathrm{ml}$. of het $\mathrm{C}$ protein.

Time of heating at $60^{\circ}$ (min.)

\begin{tabular}{lccc} 
Enzyme preparation & $\overbrace{0}$ & \multicolumn{7}{c}{$\begin{array}{c}77 \\
\text { Activity (units/0.2 ml.) }\end{array}$} \\
Wild-typc & $\overbrace{44}$ & 42 & 34 \\
Heterocaryon & 30 & 6 & $2^{*}$ \\
Mixture & 70 & 50 & 32
\end{tabular}

* This rate probably corresponds to nearly zero activity, since no correction was made for unspecific oxidation of TPNH.

\section{Heat stabilities}

Enzyme preparations from both $a m^{1}+a m^{2}$ and $a m^{1}+a m^{3}$ heterocaryons were less stable to heat than those from wild-type organism. The thermolability of $a m^{1}+a m^{2}$ preparations was marked at all stages of purification; that of $a m^{1}+a m^{3}$ preparations was much less so. Rather consistent results have been obtained with crude filtrates and ammonium sulphate fractions (Table 2). Ammonium sulphate fractions of both wild-type and heterocaryons were much less stable than crude extracts, but were stabilized somewhat by dialysis. An experiment in which dialysed ammonium sulphate fractions of wild type and het $\mathrm{C}\left(a m^{1}+a m^{2}\right)$ were heated separately and in mixture showed a large difference in thermostability, without any significant effect of the one preparation on the stability of the other (Table 3). This indicates strongly that the difference in thermostability lies in the enzyme itself (or in something bound to the enzyme), and does not depend on, for example, differences in protein or salt concentrations.

Comparative work on heat stabilities of more purified fractions has encountered difficulties. Different gel eluates from the same source, or supposedly 


\section{Glutamic dehydrogenase of Neurospora}

similar fractions prepared in different experiments, have sometimes differed markedly in stability, and it seems probable that differences in respect of traces of stabilizing or destabilizing substances, as well as in protein concentration, are involved. Different gel eluates may be more heterogeneous in these respects than cruder fractions. In spite of this variability, purified fractions from $a m^{1}+a m^{2}$ heterocaryons have always been less stable to heat than comparable preparations from wild type.

\section{Effect of temperature on reaction rate}

A further peculiarity of enzyme from $a m^{1}+a m^{2}$ was shown in experiments on the effect of temperature on the rates of the forward and back reactions. Some of the data obtained are shown in Fig. 1. Arrhenius plots for wild-type enzyme were not strictly linear, either for the forward or the back reactions, but tended to be slightly concave downwards, with a pronounced dip at the
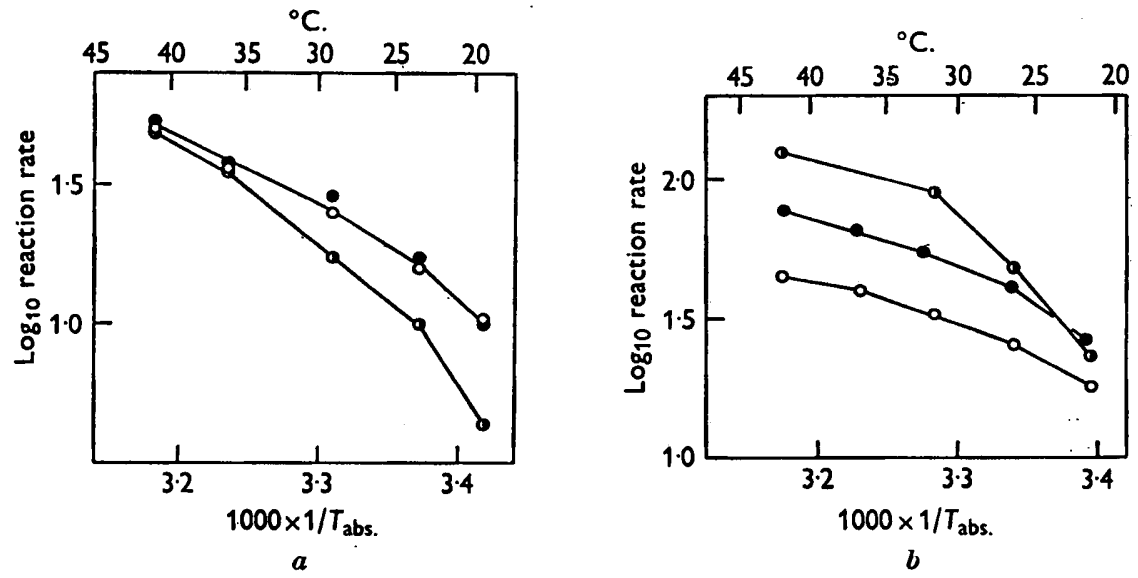

Fig. 1. Temperature dependence of forward and back reaction rates with various enzyme preparations. The amount of protein used/assay are given in parentheses. (a) For-

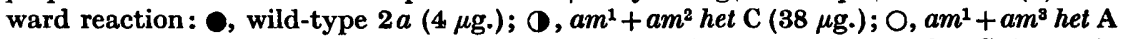
(19 $\mu$ g.). (b) Back reaction: 0 , wild-type $2 a(1 \mu \mathrm{g}$.$) ; \left(a m^{1}+a m^{2}\right.$ het $\mathrm{C}$ (23 $\mu \mathrm{g}$.); $\mathrm{O}, a m^{1}+a m^{3}$ het B $(7 \cdot 5 \mu \mathrm{g}$.$) .$

lower end of the temperature range. Such deviations from linearity are not uncommon in enzyme-catalysed reactions (Dixon \& Webb, 1958). Over the range $25^{\circ}-40^{\circ}$, where the curves are approximately linear, the apparent activation energies for the forward and back reactions catalysed by wildtype enzyme were about 11,400 and 8000 cal./mole respectively. The data for $a m^{1}+a m^{3}$ are not significantly different from those for wild-type. In the case of $a m^{1}+a m^{2}$ heterocaryon preparations, however, the apparent activation energies over the range $20^{\circ}-30^{\circ}$ were about twice as great as those for wildtype for both forward and back reactions. Up to about $30^{\circ}, Q_{10}$ values of about 3, or even more, were characteristic of $a m^{1}+a m^{2}$ enzyme, compared with less than 2 for wild-type enzyme. This was true in experiments both with 
het $\mathrm{C}$ and with het $\mathrm{D}$. Above $35^{\circ} a m^{1}+a m^{2}$ preparations became much more similar to wild-type in their response to temperature.

One possible explanation of this property of $a m^{1}+a m^{2}$ enzyme is that it tends to become converted to a more active form as the temperature is increased between $20^{\circ}$ and $35^{\circ}$. This explanation is supported by experiments in which it was shown that the enzyme was more active after brief warming in

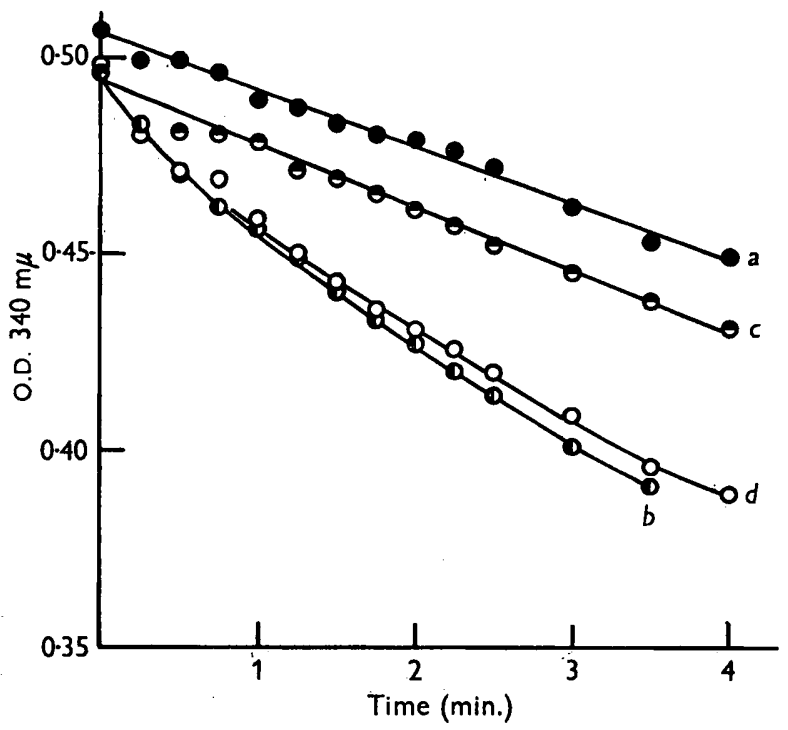

Fig. 2. Reversible activation of $a m^{2}+a m^{2}$ by warming. Activity assays at $20^{\circ}$ on $80 \mu \mathrm{g}$. protein from het $\mathrm{D}:(a)$ no pretreatment; (b) enzyme in $0 \cdot 1 \mathrm{M}$-sodium phosphate (pH 8), incubated $12 \mathrm{~min}$. at $34^{\circ}$, cooled, and assayed within $2 \mathrm{~min}$. $\left(4 \mathrm{~min}\right.$. at $34^{\circ}$ gave the same result); (c) enzyme $12 \mathrm{~min}$. at $34^{\circ}$ followed by $22 \mathrm{~min}$. at $20 \cdot 5^{\circ}$; $(d)$ enzyme $12 \mathrm{~min}$. at $34^{\circ}, 22 \mathrm{~min}$. at $20 \cdot 5^{\circ}$, and a further $3 \mathrm{~min}$. at $34^{\circ}$.

the absence of substrates than when it had not been so treated, the temperature of assay being the same in both cases. Most of the extra activity was lost during 20 min. at $20^{\circ}$, but it could be regained by repeated warming (Fig. 2). The rate of the reaction catalysed by the activated enzyme tended to fall off rather rapidly (Fig. 2), as if activity were being lost during the course of the reaction. This capacity for reversible activation by mild heat is qualitatively similar to that shown by enzyme from $a m^{2 l}$ (Fincham, 1957), a mutant secondarily derived from $a m^{2}$ (Fincham \& Pateman, $1957 b$ ), though the effect is less in the present case. Wild-type enzyme shows no activation under the same conditions (Fincham, 1957).

Experiments in which mixtures of wild-type and $a m^{1}+\dot{a} m^{2}$ enzymes were assayed for activity at different temperatures gave no indication that the activity of either preparation was being affected by mixture with the other (Table 4). This, again, tends to support the hypothesis of a difference between two kinds of enzyme. 
Table 4. Effect of temperature on reaction rate with Neurospora crassa wildtype and het $C\left(\mathrm{am}^{1}+\mathrm{am}^{2}\right)$ glutamic dehydrogenase preparations separately and in mixture

Each reaction mixture contained $2 \mu \mathrm{g}$. wild-type (5a) protein, or $27 \mu \mathrm{g}$. het $\mathrm{C}$ protein, or both.

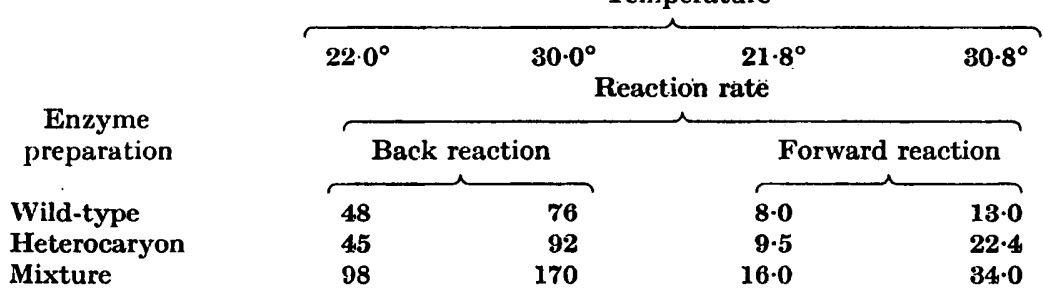

\section{Michaelis constants}

Michaelis constants for all five substrates were determined for partially purified preparations from wild-type and the two kinds of heterocaryons. The values, which, in the case of wild-type, are in reasonable agreement with those previously reported (Fincham, 1957), are shown in Table 5. Some variation is evident in the estimates for wild-type; some of this could be due to small differences in temperature and $\mathrm{pH}$ value. None of the differences between the heterocaryons and wild-type can be considered as outside the range of experimental variation, except the lower affinity for glutamate shown by the $a m^{1}+a m^{3}$ preparations, and, possibly, the rather high affinity for ammonium ion shown by the $a m^{1}+a m^{2}$ preparation. As a check on the difference in Michaelis constants for glutamate, wild-type and het A preparations were compared in the same experiment under conditions of identical phosphate concentration, $\mathrm{pH}$, and temperature. The data, and those for separate experiments on het $\mathrm{B}$ and het $\mathrm{C}$ preparations, are shown in Fig. 3. There seems to be no doubt that the difference between $a m^{1}+a m^{3}$, on the one hand, and

Table 5. Michaielis constants for glutamic dehydrogenase preparations from

Neurospora crassa wild-type and heterocaryons

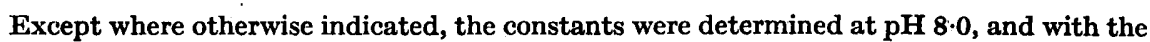
concentrations of the non-varying components of the reaction mixtures as in the standard assays systems

\begin{tabular}{lccccc} 
& \multicolumn{5}{c}{$K_{m}\left(m o l a r\right.$ concentration $\left.\times 10^{5}\right)$} \\
Strain & Glutamate & $\begin{array}{c}\alpha \text {-Ketogluta- } \\
\text { rate }\end{array}$ & NH $_{4}{ }^{+}$ & TPNH & TPN \\
Wild type ST $A$ & 980 & $390(1)$ & $110(2)$ & $3(1,3)$ & 5 \\
(2 preparations) & 750 & $310(1)$ & $100(2)$ & $3(1,2)$ & 6 \\
Wild type 5a & $1100^{*}(4)$ & - & - & - & - \\
$a m^{1}+a m^{2}$ het $\mathrm{D}$ & 900 & $320(1)$ & $50(2)$ & $3(1,2)$ & 6 \\
$a m^{1}+a m^{2}$ het $\mathrm{C}$ & $800^{*}(4)$ & - & - & - & - \\
$a m^{1}+a m^{3}$ het B & $3000^{*}(5)$ & 420 & $100(2)$ & $3.5(2)$ & $4(5)$ \\
$a m^{1}+a m^{3}$ het A & $2700^{*}(4)$ & - & - & - & -
\end{tabular}

* See Fig. 3.

Notes. (1) $\mathrm{NH}_{4} \mathrm{Cl}$ at $10 \mathrm{~mm}$; (2) $\alpha$-ketoglutarate at $12 \mathrm{~mm}$; (3) $\alpha$-ketoglutarate at $10 \mathrm{~mm}$; (4) $\mathrm{pH} 7 \cdot 9$; (5) $\mathrm{pH} 7 \cdot 85$. 
$a m^{1}+a m^{2}$ and wild-type, on the other, is significant. The possibility that $a m^{1}+a m^{3}$ preparations contained an inhibitor having the effect of reducing affinity for glutamate, or, conversely, that they lacked an activator present in wild-type preparations and having the opposite effect, receives no support from the experiments on mixed preparations shown in Table 6. While some degree of interaction is not ruled out, it is clear that neither type of preparation acquired the properties of the other in the mixtures. It thus seems simplest to suppose that $a m^{1}+a m^{3}$ heterocaryons produce a further distinct form of glutamic dehydrogenase.

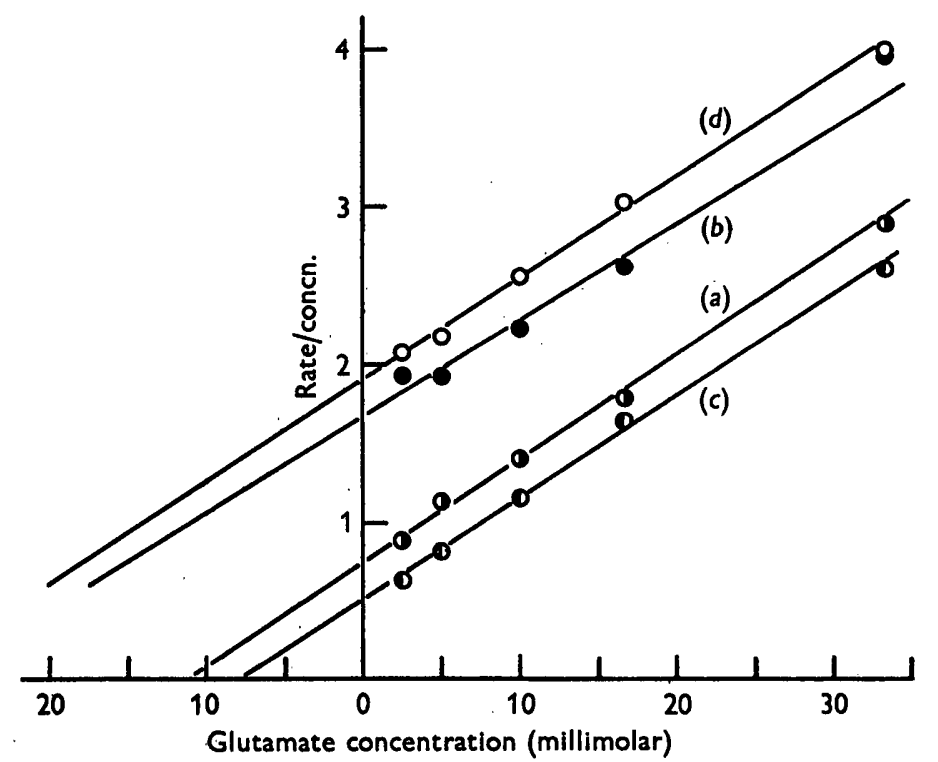

Fig. 3. Estimates of Michaelis constants for glutamic acid: (a) $4 \mu \mathrm{g}$. protein of wild-type $5 a$, $21.5^{\circ}, \mathrm{pH} 7 \cdot 9\left(\mathrm{~K}_{\mathrm{m}}=11 \mathrm{~mm}\right)$; (b) $14 \mu \mathrm{g}$. protein of $a m^{1}+a m^{3}$ het $\mathrm{A}, 21.5^{\circ}, \mathrm{pH} 7 \cdot 9$ ( $\mathrm{K}_{\mathrm{m}}=$ approx. $\left.27 \mathrm{mM}\right)$; (c) $68 \mu \mathrm{g}$. protein of $a m^{1}+a m^{2}$ het $\mathrm{C}, 22^{\circ}, \mathrm{pH} 8.0\left(\mathrm{~K}_{\mathrm{m}}=8 \mathrm{mM}\right)$; (d) $30 \mu \mathrm{g}$. protein of $a m^{1}+a m^{3}$ het $\mathrm{B}, 22^{\circ}, \mathrm{pH} 7 \cdot 85\left(\mathrm{~K}_{\mathrm{m}}=\right.$ approx. $\left.30 \mathrm{mM}\right)$.

Table 6: Effect of glutamate concentration on rate of forward reaction with Neurospora crassa wild-type and heterocaryon $\left(\mathrm{am}^{1}+\mathrm{am}^{3}\right)$ glutamic dehydrogenase preparations separately and in mixtures

In Expt. 1: $13 \mu \mathrm{g}$. protein of wild-type (5a), or $38 \mu \mathrm{g}$. protein of het A, or both. In Expt. 2: $6 \mu \mathrm{g}$. protein of wild-type (2a) or $29 \mu \mathrm{g}$. protein of het A, or both. Temperature: $21^{\circ}$ in Expt. $1 ; 22.5^{\circ}$ in Expt. 2. pH of reaction mixtures : 7.85 in Expt. $1 ; 7 \cdot 9$ in Expt. 2.

\begin{tabular}{|c|c|c|c|c|}
\hline \multirow{4}{*}{$\begin{array}{l}\text { Enzyme } \\
\text { preparation }\end{array}$} & \multicolumn{2}{|c|}{ Expt. 1} & \multicolumn{2}{|c|}{ Expt. 2} \\
\hline & \multicolumn{4}{|c|}{ Glutamate concn. (mM) } \\
\hline & $\mathbf{8} \cdot \mathbf{3}$ & $\mathbf{3 3 \cdot 3}$ & $5 \cdot 0$ & $33 \cdot 3$ \\
\hline & \multicolumn{4}{|c|}{ Reaction rate } \\
\hline Wild-type & $6 \cdot 3$ & $23 \cdot 5$ & $3 \cdot 2$ & $8 \cdot 6$ \\
\hline Heterocaryon & $\mathbf{2 \cdot 1}$ & $12 \cdot 0$ & $\mathbf{3 \cdot 8}$ & $15 \cdot 6$ \\
\hline Mixture & $8 \cdot 2$ & $33 \cdot 0$ & $7 \cdot 9$ & $\mathbf{2 6} \cdot \mathbf{4}$ \\
\hline
\end{tabular}




\section{DISCUSSION}

From the foregoing data it seems highly probable that $a m^{1}+a m^{2}$ and $a m^{1}+a m^{3}$ heterocaryons both produce peculiar kinds of glutamic dehydrogenase. The $a m^{1}+a m^{2}$ enzyme differs from wild-type enzyme in its capacity for activation by mild heat, and by its instability at higher temperatures, while the $a m^{1}+a m^{3}$ enzyme is distinguished by its high Michaelis constant for glutamate. The nature of the differences between the various kinds of enzyme is, at present, unknown. The enzyme produced by $a m^{1}+a m^{2}$ has, in its capacity for heat-activation, something in common with the enzyme produced by $a m^{22}$, an allele obtained from $a m^{2}$ by treatment with ultraviolet light (Fincham, 1957; Fincham \& Pateman, 1957b). In fact, enzyme from $a m^{1}+a m^{2}$ is quite closely similar in its activity and response to heat to that from heterocaryons between $a m^{2 l}$ and some other alleles, such as $a m^{4}$ (Fincham, 1959). It seems likely that enzymes from all these sources share a rather flexible structure which tends to assume a more nearly 'correct' configuration at higher temperatures.

The facts that it is possible to represent complementation relationships between alleles by linear maps (Catcheside \& Overton, 1959; Woodward et al. 1958; Fincham, 1959), and that, in at least one case (Giles, 1959), there seems to be a correlation between a complementation map and a chromosome map based on crossover frequencies, suggest that the complementation process involves interaction between linear structures with defects corresponding in position to the site of mutation within the chromosomal locus. One idea (Woodward et al. 1958) has been that cytoplasmic products of different alleles may undergo some kind of recombination process, analogous to crossingover between chromosomes. Such a process should lead to the formation of a wild-type product in an amount proportional to the distance apart of the lesions in the two structures. The data of Woodward et al. (1958) for the Neurospora $a d-4$ locus show a tendency, which is perhaps not entirely convincing, for pairs of alleles represented as being relatively far apart on the complementation map to produce more enzyme (in this case adenylosuccinase) than pairs closer together. However, the fact that, in the cases of two pairs of am alleles, the interaction product seems not to be wild-type enzyme, tells against any hypothesis involving crossing-over or recombination. It seems more likely that complementation, at least in the am case, involves combination of allelic products, rather than recombination. The possibility of making complementation maps would still be understandable on this basis, since products with lesions in different places might be able to 'cover' each other's deficiencies, while products with similar or effectively overlapping lesions could not do so.

There is at present nothing to show whether the molecules directly involved in complementation are protein or components of the protein-forming system (perhaps ribonucleic acid). In view of the present results, however, the idea of complementation at the protein stage becomes attractive. It has been reported (Soyama, 1958) that animal glutamic dehydrogenase can be 
dissociated into at least eight subunits, which, since they retain enzyme activity, are probably identical. If the Neurospora enzyme is similar in this respect, it may be that each mutant $a m$ allele is responsible for the formation of a more or less defective subunit, and that subunits, which, in heterocaryons, may be derived from different alleles, become polymerized after synthesis. It is easy to imagine that two individually defective polypeptide chains could provide mutual support and form a 'correctly' folded protein through copolymerization. An attractive feature of this hypothesis, which is essentially the same as that advanced by Catcheside \& Overton (1959); is that it is subject to experimental test, since; if it is true; it should be possible to demonstrate the complementation reaction in vitro under appropriate conditions. A model of the kind of experiment required is provided by the recent work of Singer \& Itano (1959) on the dissociation and reassociation of haemoglobin subunits. Complementation in vitro has been demonstrated for certain pairs of ad-4 (adenylosuccinase-deficient) mutants of Neurospora (Woodward, 1959).

Considerable attention has been given in recent years to the question of the definition of genetic units. Benzer (1957) has proposed that the functional unit should be defined as the cistron. According to his definition, when two mutant genomes, introduced into the same cell, produce a defective phenotype, then the mutations are in the same cistron; - when a non-defective phenotype results, the mutations are in different cistrons. The delimitation of cistrons is not always straightforward, however, since it depends on what one is prepared to accept as a non-defective phenotype. If ability to grow more or less normally on minimal medium is adopted as the criterion, then the phenomenon of inter-allele complementation means that several chromosomal loci in Neurospora, which appear to be units of function of some sort since they are concerned with single enzymes, have each to be subdivided into several cistrons. This rather unsatisfactory conclusion can be avoided, however, if one stipulates that the phenotype has to be non-defective at the enzyme level before two mutants are recognized as belonging to different cistrons. If the situation shown in the present paper is general in cases of inter-allele complementation, then all the recognized loci in Neurospora may, after all, be cistrons in this qualified sense.

\section{REFERENCES}

Benzer, S. (1957). The elementary units of heredity. The Chemical Basis of Heredity. Eds. McElroy, W. D. \& Glass, B., p. 848. Baltimore: Johns Hopkins Press.

Catcheside, D. G. \& Overton, A. (1959). Complementation between alleles in heterocaryons. Cold Spr. Harb. Symp. quant. Biol. 23, 137.

Colowick, S. P. \& Kaplan, N. O. (1955). Methods in Enzymology, vol: 1, p. 835. New York: Academic Press.

Dixon, M. \& WEBB, E.C. (1958). Enzymes, p. 782. London: Longmans, Green and Co.

Fincham, J. R. S. (1957). A modified glutamic acid dehydrogenase as a result of gene mutation in Neurospora crassa. Biochem. J. 65, 721.

Fincham, J. R. S. (1959). The role of chromosomal loci in enzyme formation. Proc. Xth Int. Congr. Genetics, , I, 355. 
Fincham, J. R. S. \& Pateman, J. A. (1957 a). A new allele at the am locus in Neurospora crassa. J. Genetics, $55,456$.

Fincham, J. R. S. \& Pateman, J. A. (1957b). Formation of an enzyme through complementary action of mutant alleles in separate nuclei in a heterocaryon. Nature, Lond. 179, 741.

Giles, N. H. (1959). Mutations at specific loci in Neurospora. Proc. Xth Int. Congr. Genetics, I, 261.

Grles, N. H., Partridge, C. W. H. \& Nelson, N. J. (1957). The genetic control of adenylosuccinase in Neurospora crassa. Proc. nat. Acad. Sci., Wash. 43, 305.

Hartman, P. E., Hartman, Z., Serman, D. \& Loper, J. C. (1958). Genetic complementarity in histidineless Salmonella typhimurium. Proc. Xth Int. Congr. Genetics, II, 115.

Lowry, O. H., Rosebrough, N. J., Farr, A. L. \& Randall, R. J. (1951). Protein measurement with the Folin phenol reagent. J. biol. Chem. 193, 265.

NewmeYer, D. (1957). Arginine synthesis in Neurospora crassa: genetic studies. J. gen. Microbiol. 16, 449.

Pateman, J. A. \& Fincham, J. R. S. (1958). Gene-enzyme relationships at the am locus in Neurospora crassa. Heredity, 12, 317.

Singer, S. J. \& Itano, H. A. (1959). On the asymmetrical dissociation of human hemoglobin. Proc. nat. Acad. Sci., Wash. 45, 174.

Soyama, T. (1958). Molecular size and polymerization of crystalline glutamic dehydrogenase. Osaka Daigaku Igaku Zasshi, 10, 131. (Chem. Abstr. 52, 9266.)

VogeL, H. J. \& BonNER, D. M. (1956). A convenient growth medium for Neurospora (medium N). Microbial Genetics Bull. no. 13.

Woodward, D. O. (1959). Enzyme complementation in vitro between adenylosuccinase mutants of Neurospora crassa. Proc. nat. Acad. Sci., Wash. 45, 846.

Woodward, D. O., Partridge, C. W. H. \& Giles, N. H. (1958). Complementation at the ad-4 locus in Neurospora crassa. Proc. nat. Acad. Sci., Wash. 44, 1237. 